\title{
マグニチュードの深さおよび時間的 分布についての一考察
}

\author{
東京大学理学部地球物理学教室 栗本広 \\ (昭和 36 年 9 月 1 日受理)
}

A Study on Frequency Distribution of Earthquake
Magnitude, having Respects to Depth and Time

Hiroshi Kurimoto

Geophysical Institute, Faculty of Science, the University of Tokyo

(Received Sep. 1, 1961)

Taking into account an idea of Farthquake Province proposed by C. Tsuboi, we have derived twelve geographical regions from data for the earthquakes of magnitudes larger than 4 which occurred in and near Japan from 1926 to 1956.

We applied a statistical test on null hypothesis to a problem on correlations between magnitude and depth, and between magnitude and time, and divided the data for earthquakes in each one of these twelve regions into two or three classes by next criterions, i. e., 0-30 $\mathrm{km}$ and 40-60 $\mathrm{km}$ depths, and before, in, and after the year in which the largest earthquake occurred for these thirty one years.

Some correlations between magnitude and depth for regions off Fukushima Prefecture and off Tokati were found, and between magnitude and time, for every regions.

\section{§1. まえがき}

C. Tsuboi (1958) の Earthquake Province の考えにしたがつて, Catalogue of Major Earthquakes which occurred in and near Japan (1926-1956) に記載された $M \geq 4$ の地 震を地域分けし，12 コの集まりを得た。この場合は, サンプリングの方法が坪井の場合と異 なるがこれは §2で述べる。

上記の各グループについて, $M$ の頻度分布が哚さおょび時間に関して, 統計的に有意な変 動を示すかどうかを調べた，その結果について報告する.

\section{§2. クループ分け}

日本列島を含む細長い地域を緯度経度それぞれ $0.5^{\circ}$ の角柱に分け, そのうち, Fig. 1 に 示すように, 31 年間に 10 コ以上の地震が起つたものだけを採用し, その年頻度の系列につい て，相互の相関係数を求めた．この結果 ${ }_{99} \mathrm{C}_{2}=4851$ この相関係数が得られるが，これらの位 置関係をも考虑して表示することは困難であるし，また無理して表現しても意味がないと思わ れるので, Fig. 2 のごとく簡単に表現した. 図中行および列の番号は，Fig. 1 における各四 


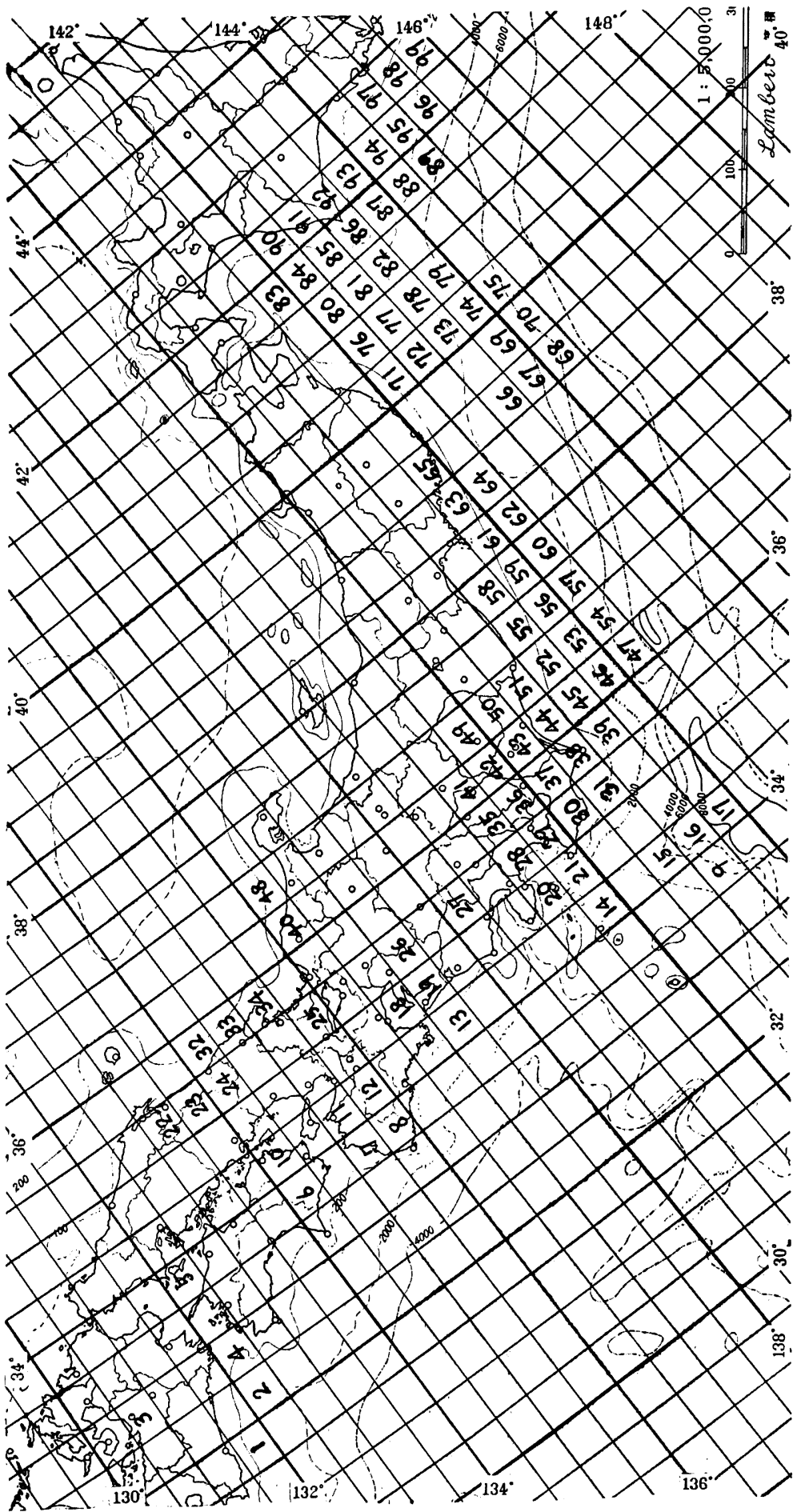

Fig. 1. Division of Japanese islands into compartments which consist of $0.5^{\circ}$ longitude and latitude. Each numbered compartment contains more than 10 earthquakes from 1926 to 1956. 


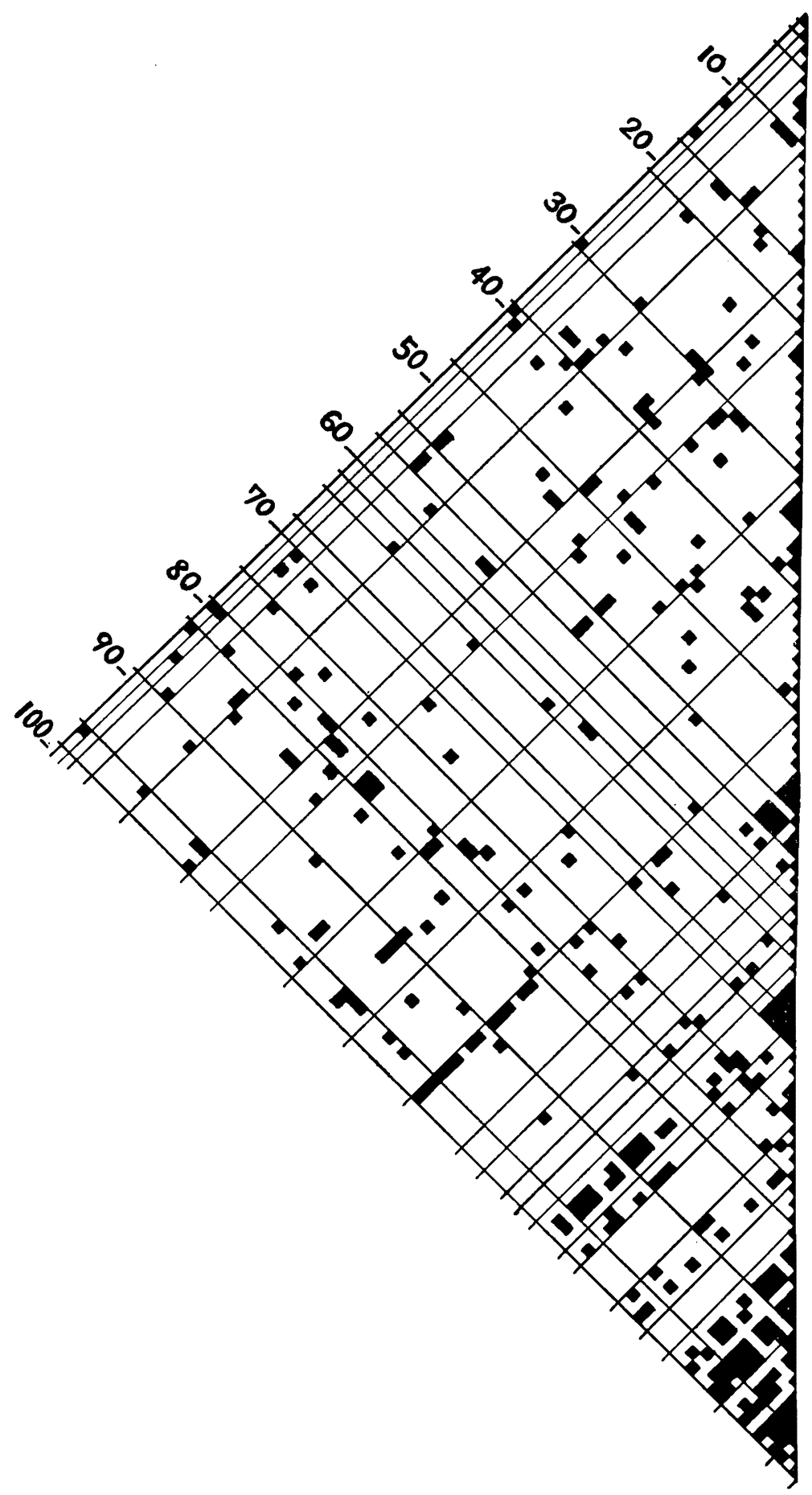

Fig. 2. Symbolic representation of correlation coefficients. The numbers correspond to those of compartments in Fig. 1. Black squares correspond to the coefficients larger than 0.40 . 


\section{$f(r)$}

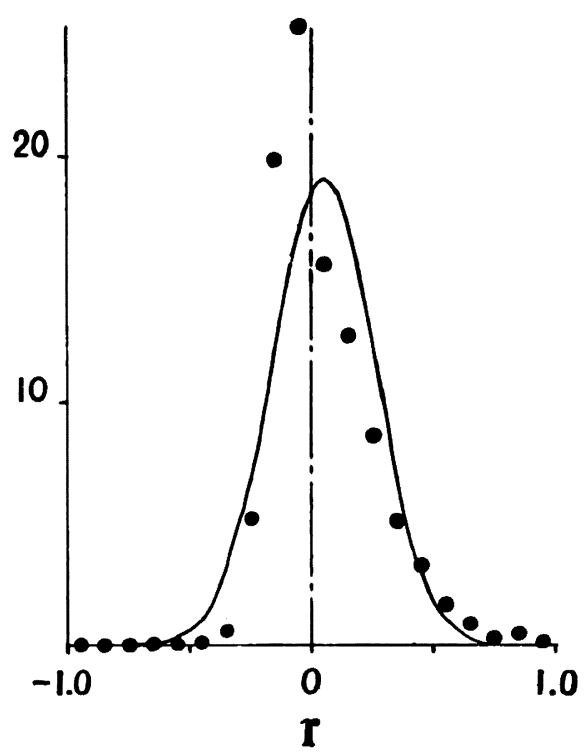

(a)

\section{$f(r)$}

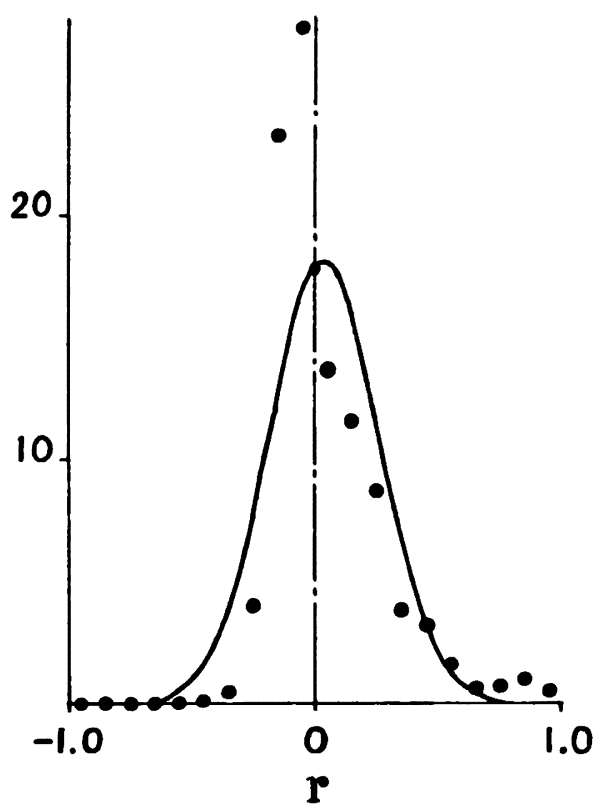

(b)

\section{$f(r)$}

\section{$f(r)$}

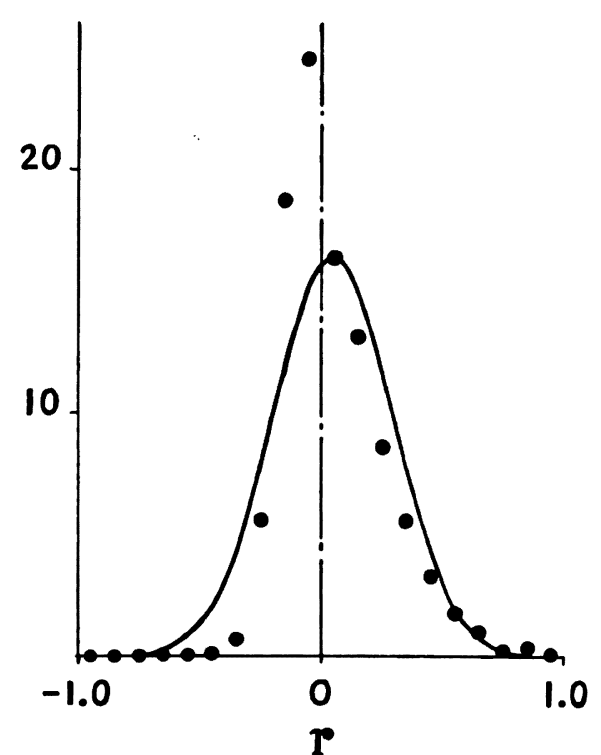

(c)

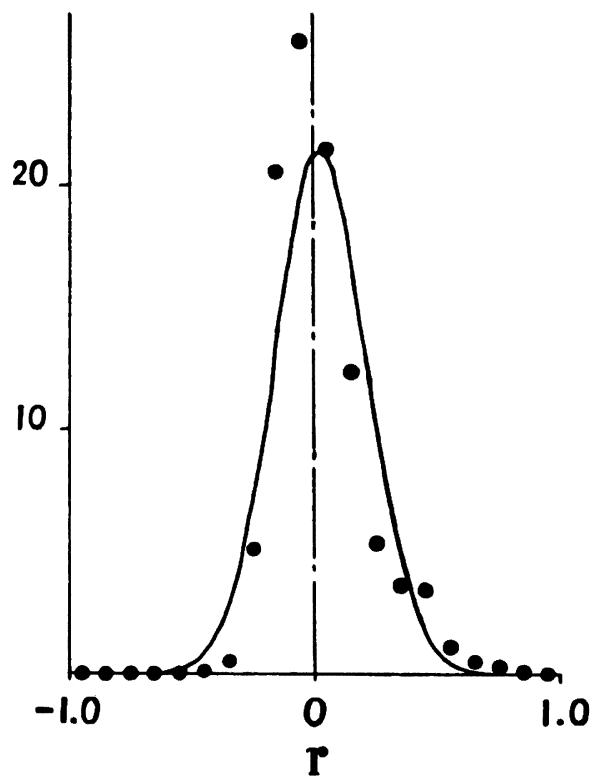

(d)

Fig. 3. Frequency distributions of correlation coefficients; (a) between every two compartments, (b) between compartments where 10-19 earthquakes occurred from 1926 to 1956 , (c) between compartments where more than 20 earthquakes ocurred in these years, (d) which C. Tsuboi has calculated in a different way. 
角形の番号に対応するので, これら両図 を対照すれば相関係数と位置関係がある 程度判断できると思う。

グループ分けに用いられる相関係数の 頻度分布は Fig. 3 に示すように, やや 正規型に近いが，フィッシャー（昭和 27 年）によつて $k$ 統計量および $g$ 統計量 を求めて，統計的検定を行なつた結果， Table 1 のようになつた. これによれ ば，この分布は正規分布よりも，かなり 正の方に偏り, かつ平均值の近傍に密集 し過ぎたものであることがわかる。ま た, 各角柱に含まれる地震の数によつて, それらの相関係数の分布が有意に変動す るかどうかを確かめるために，地震の数 が 10〜19 コの角柱どうしから求めた相 関係数の分布，および全相関俰数からそ れらを除いた残りの分布について, 上と 同様の手続きを行なつたが，その結果は 同表の 2 列および 3 列に示してある。表 によれば, 地震の数が少ないと, 分布の 偏りおよび尖りが約 2 倍だけ, 残余の分 布よりも大きい，すなわち正規分布から ますをす離れたものとなることがわか る.この傾向が, 地震の数が少ないこと のみによるとすれば, 全相関係数の分布もやはりこの傾向があるので, 全体として各角柱の中 に入る地震の数が少な過ぎることなる。しかし事柄はそう簡単ではないようである．Table 1 の第 4 列に, 坪井の場合の相関係数の頻度分布について上と同様の検定を行なつた結果を示 す。この場合もやはり上と同様の傾向がある．Fig. 3 (a), (b), (c), (d) にそれぞれ上の 4 つの 場合の頻度分布およびそれと同じ平均值および分散の正規分布を示す.

このように全相関係数の標本分布は正規型とはかなり異なるが，他の型の分布を考えてもこ
Table 1. Frequency distributions of correlation coefficients. The first, second, third, and fourth columns correspond to (a), (b), (c) and (d) in Fig. 3 respectively.

\begin{tabular}{|c|c|c|c|c|}
\hline$r$ & Total & $10-19$ & $\begin{array}{c}\text { Total } \\
-(10-19)\end{array}$ & C. Tsuboi \\
\hline$-1.0 \sim$ & 0 & 0 & 0 & 0 \\
\hline$-0.9 \sim$ & 0 & 0 & 0 & 0 \\
\hline$-0.8 \sim$ & 0 & 0 & 0 & 0 \\
\hline$-0.7 \sim$ & 1 & 0 & 1 & 0 \\
\hline$-0.6 \sim$ & 1 & 0 & 1 & 0 \\
\hline$-0.5 \sim$ & 4 & 1 & 3 & 2 \\
\hline$-0.4 \sim$ & 29 & 5 & 24 & 10 \\
\hline$-0.3 \sim$ & 251 & 48 & 203 & 96 \\
\hline$-0.2 \sim$ & 961 & 282 & 679 & 387 \\
\hline$-0.1 \sim$ & 1225 & 336 & 889 & 489 \\
\hline $0 \sim$ & 757 & 166 & 591 & 404 \\
\hline $0.1 \sim$ & 616 & 141 & 475 & 233 \\
\hline $0.2 \sim$ & 419 & 106 & 313 & 101 \\
\hline $0.3 \sim$ & 248 & 46 & 202 & 68 \\
\hline $0.4 \sim$ & 159 & 39 & 120 & 64 \\
\hline $0.5 \sim$ & 85 & 19 & 66 & 20 \\
\hline $0.6 \sim$ & 44 & 7 & 37 & 10 \\
\hline $0.7 \sim$ & 17 & 8 & 9 & 6 \\
\hline $0.8 \sim$ & 25 & 12 & 13 & 2 \\
\hline $0.9 \sim$ & 9 & 6 & 3 & 0 \\
\hline$S$ & 4851 & 1222 & 3629 & 1892 \\
\hline$k_{1}$ & .051 & .044 & .047 & .024 \\
\hline$k_{2}$ & .044 & .049 & .060 & .035 \\
\hline$k_{3}$ & .010 & .015 & .014 & .0067 \\
\hline$k_{4}$ & .0088 & .013 & .012 & .0053 \\
\hline$g_{1}$ & $\begin{array}{r}1.08 \\
\pm \quad .03\end{array}$ & $\begin{array}{r}1.42 \\
\pm \quad .07\end{array}$ & $\begin{array}{l}.923 \\
\pm .04\end{array}$ & $\begin{array}{r}1.05 \\
\pm \quad .06\end{array}$ \\
\hline$g_{2} *$ & $\begin{array}{r}4.48 \\
\pm \quad .05\end{array}$ & $\begin{array}{r}5.46 \\
\pm \quad .14\end{array}$ & $\begin{array}{r}3.32 \\
\pm .08\end{array}$ & $\begin{array}{r}4.43 \\
\pm \quad .11\end{array}$ \\
\hline
\end{tabular}




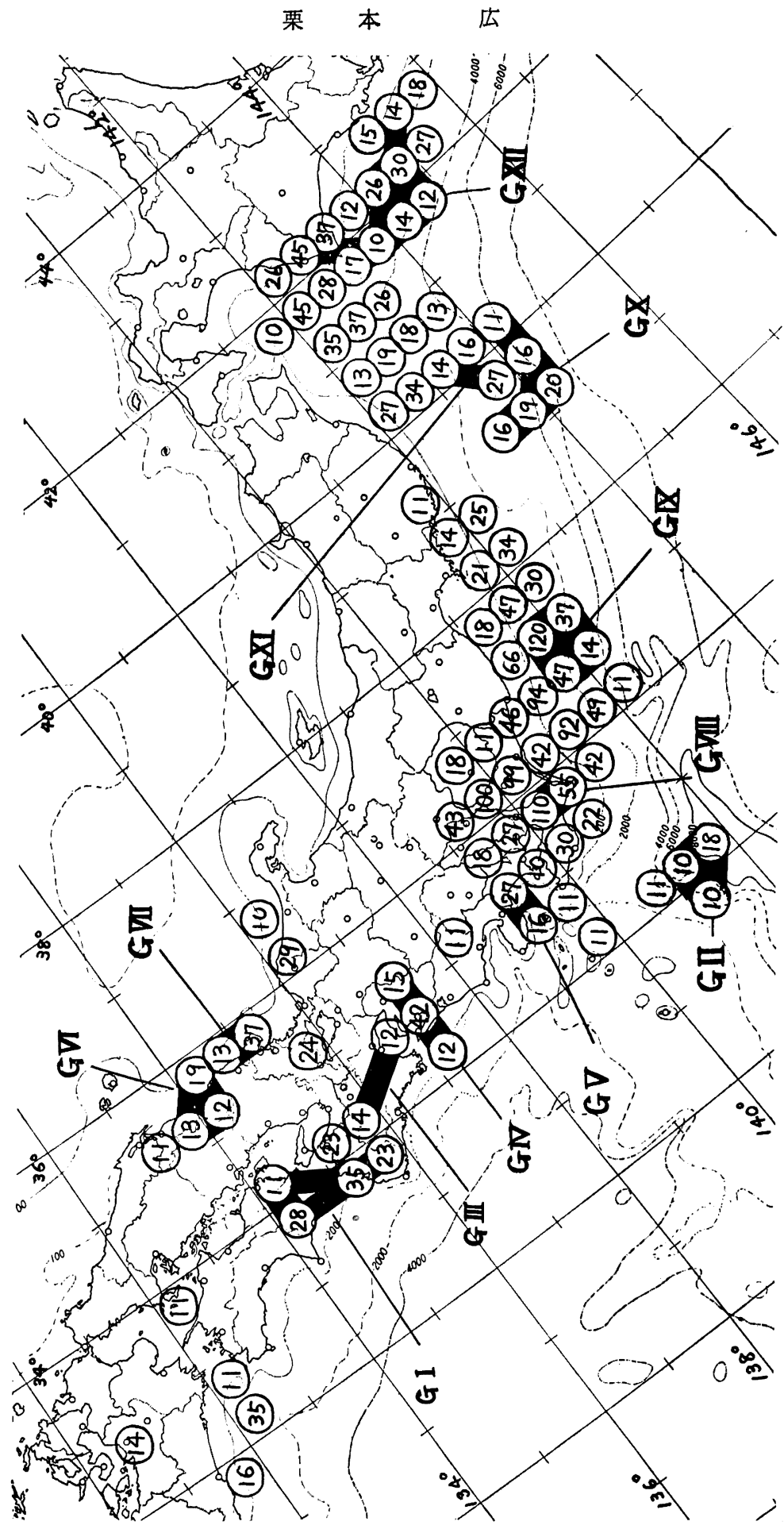

Fig. 4. Geographical regions. Number in each circle shows number of earthquakes of magnitudes larger than 4 which occurred in a corresponding compartment from 1926 to 1956. 
の場合あまり意味がないから，一応正規分布を仮定する。すると，Fig. 3 (a) に示すような正 規分布において, 有意水準 $1 \%$ に対する相関係数の限界值は \pm 0.6 位の值となる。実際は, こ の限界值をやや大きく採つておけば安全であるから，この場合 \pm 0.7 を採用した。
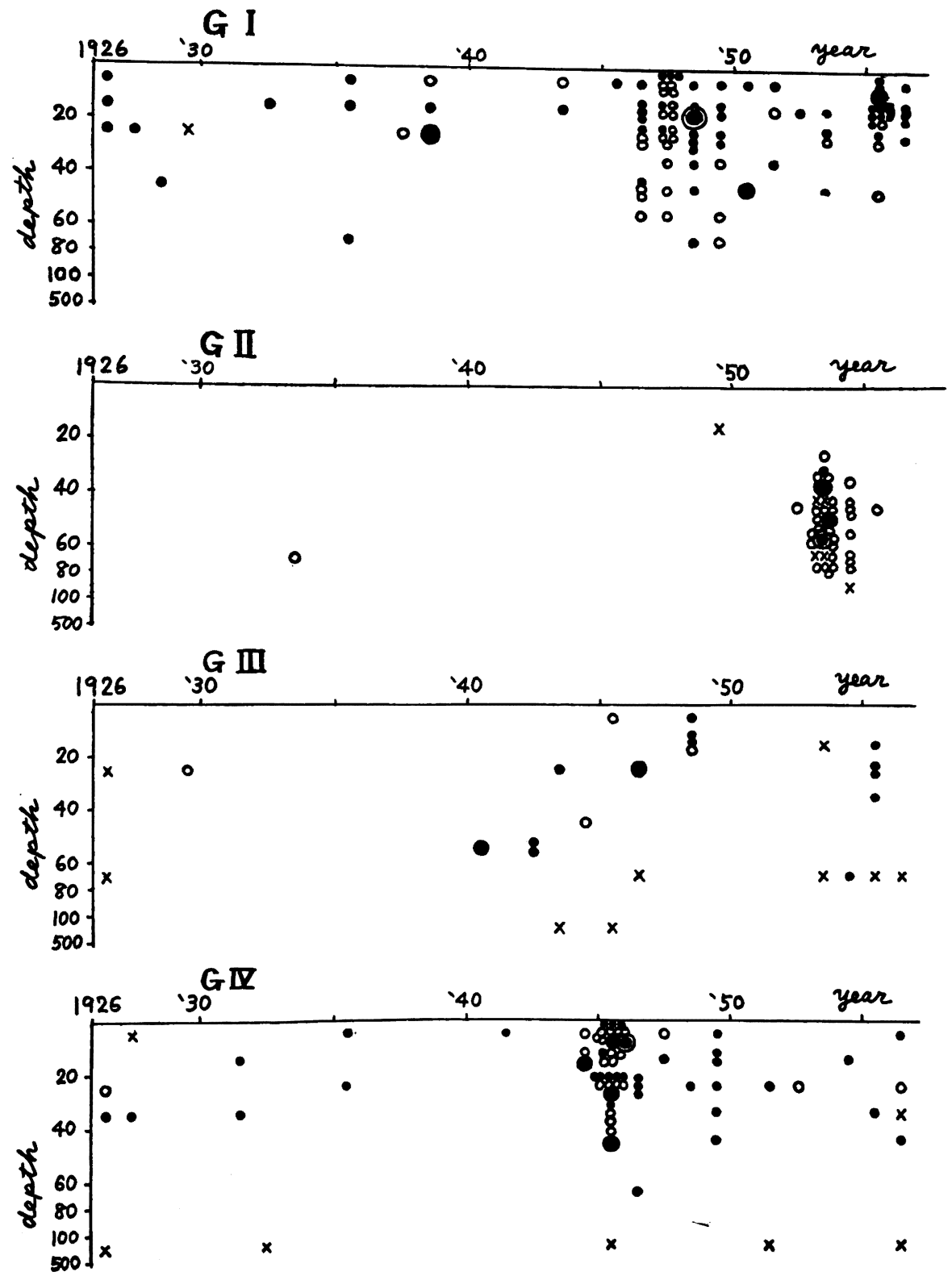

Fig. 5 

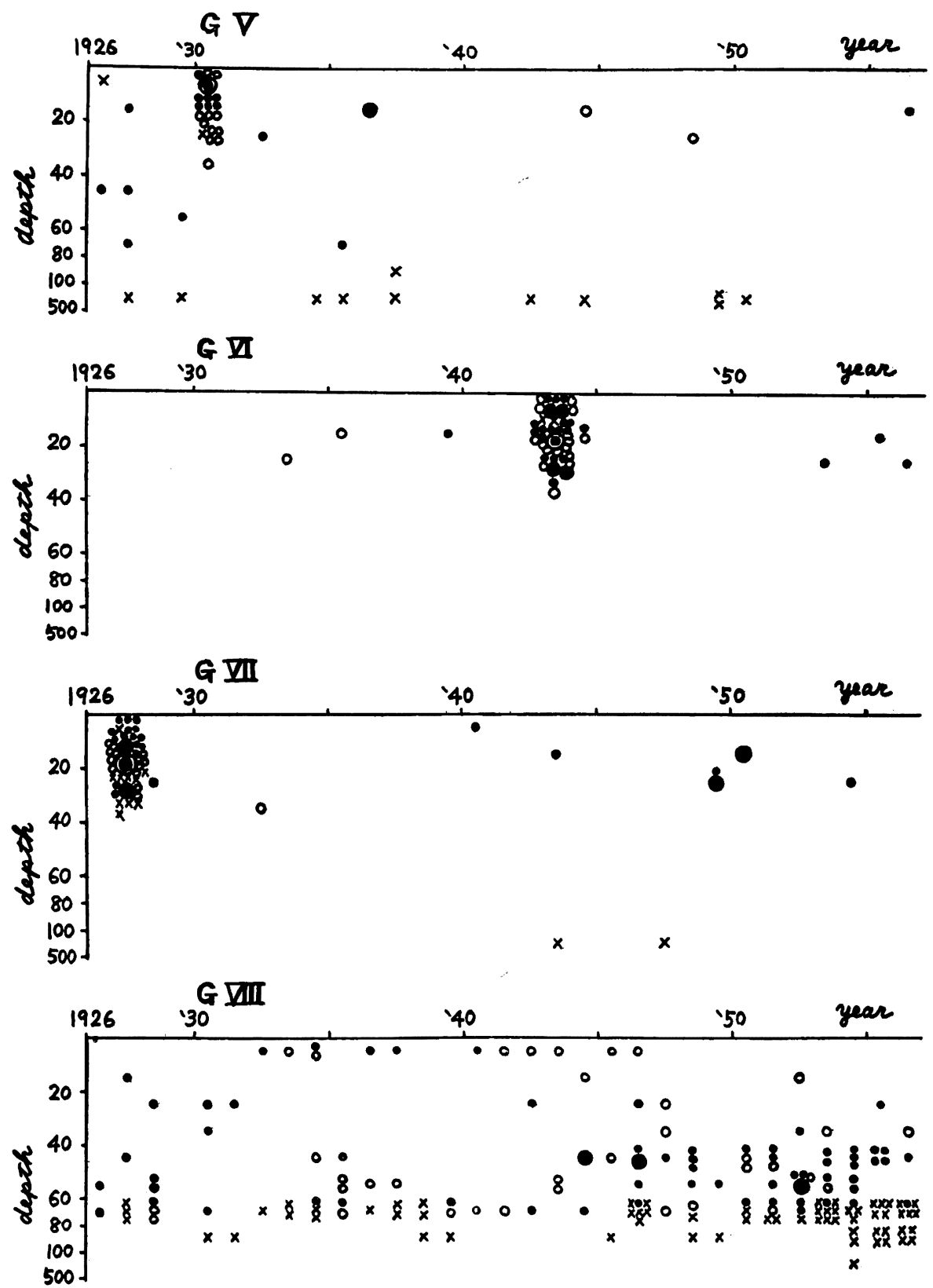

Fig. 5 

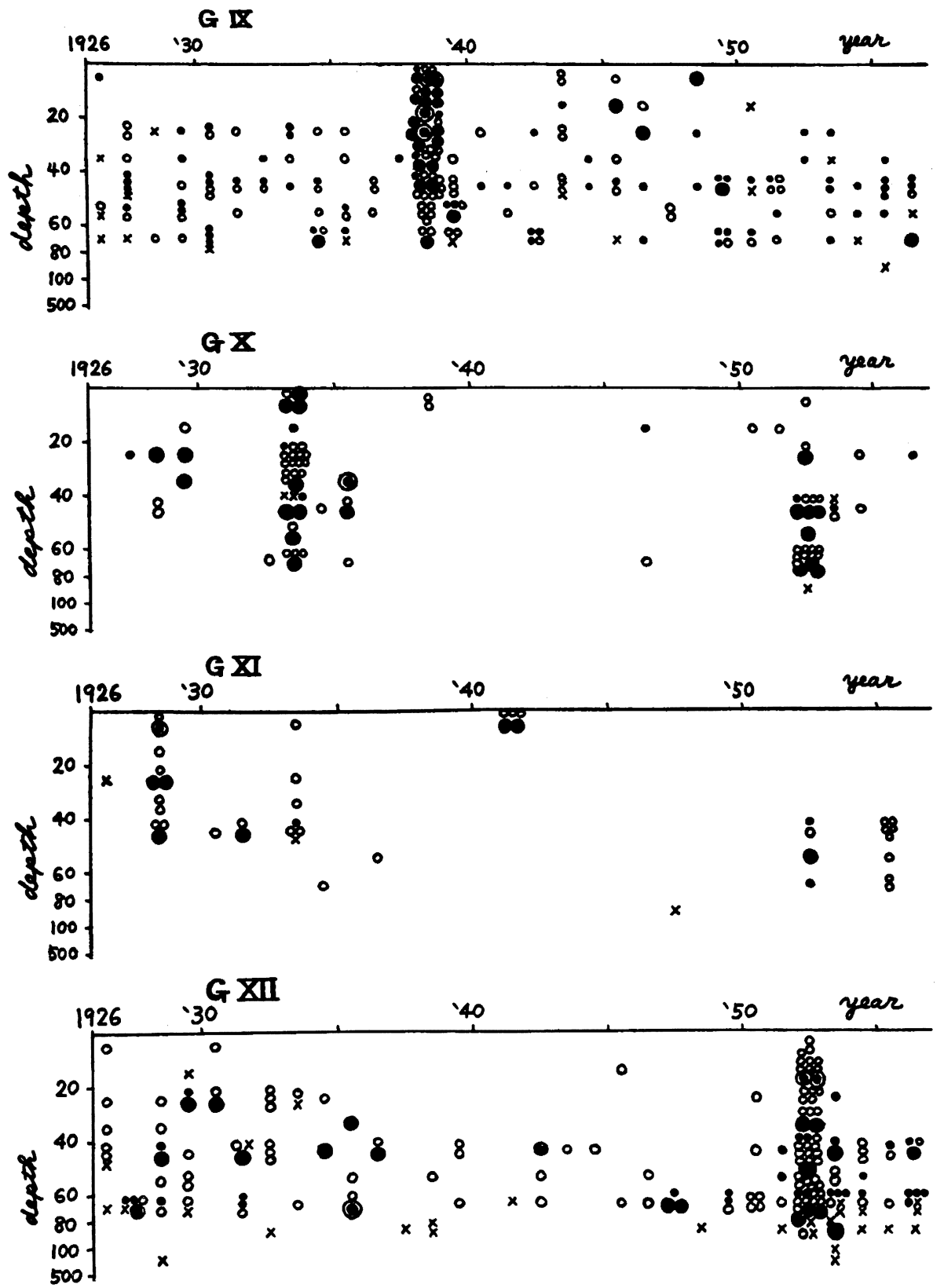

Fig. 5. Distribution of magnitude, depth, and time. Small black circle, small white circle, large black circle, and double circle show magnitudes 4.0-4.9, 5.0-5.9, 6.0-6.9, and 7.0-7.9 respectively.

このようにして，相関があると認められる角柱どうしを地図の上で結んでみると，2, 3 の例 外はあるが, 大体問題なしに Fig. 4 における G-II, V, VI, VII, VIII, IX, X, XI, XII の 
各グループが分けられた。 ただし，G-I, III, IV の各グループは例外で，グループ内に含まれ る角柱相互の相関係数の值が $0.4 \sim 0.6$ であり，0.7 よりも小さいが，しかしそのグループ外 の角柱との間のその值よりははるかに大きいものである。また，グループ分けしてないもの は，近接した角柱間の相関係数の值が 0.7 以下であり，かつ上の例外グループのような関係も 認められないものである。 もちろん，グループ分けは，これらの相関係数の大小のみによつて 簡単に行なわれ得ない。この事情は，Fig. 2 を見ればよく判ると思う。すなわち，地理的に 大部離れた角柱どうしの間でも相関係数が 0.4 以上になる場合がかなりあるからである.をた， Fig. 2 の結果を忠実に，地図上に画いてみても，ただ混乱を招くばかりである.

\section{§3. M の深さおよび時間分布}

前節で得られた 12 コのグループそれぞれについて，その中での地震活動のありさまを概観 するために，年別に各地震の $M$ を深さ軸にプロットした. Fig. 5 にそれらを示してある. 地震活動を記述するのに必要な事柄は, 現在のところ, 大きさ $(M)$, 場所 $(x, y, z)$, 時間 $(t)$ が考えられるが，ここでは簡単のために，大きさ $(M)$ と場所（ある地域の深さ）および大き さと時間（年単位）の二つに分けて現象を取扱つた。

まず，大きさと場所については，各グループについて，それぞれに属する地震を深さが 0〜 $30 \mathrm{~km}, 40 \sim 60 \mathrm{~km}$ の範囲にある 2 群に大別し, 浅い方と深い方とで地震の $M$ の分布が統 計的に有意に変つているかどうかを調べる，言い換えれば，2つの属性 $M$ および深さ $D$ が 互いに独立であるときに，実際観測から得られた頻度分布と同等またはそれ以上に期待頻度分 布から離れた頻度分布を得る確率 $P$ を計算し，この $P$ の值の大小によつて,「2つの属性 $M$ および $D$ が互いに独立である」という仮説の取捨を行なう。この $P$ の值を佐藤 (昭和 25 年) にしたがつて計算した。 Table 2 はこれらの結果を示したものである. 表中， $P$ の項の最初 に，カッコでくくつた数字 (4567), (567) などは検定に用いたサンプルの $M$ の範囲を示す. すなわち前者は $M$ が 4 の地震まで含むが，後者はそのような小さい地震を除いて統計したと いう意味である。

つぎに，大きさと時間について，前と同様の検定を行なう。この場合，時間の単位を 1 年と し，つぎのような大まかな時代分けを行なつて，各時期の中に起つた地震の $M$ の頻度分布が 有意に変つているかどうかを調べる。すなわち，上記のグループ内で最大の地震を含む 1 年間 を中期とし，その前後の何年間かを前期および後期とした。 このうち G-III, VIII，X の 3 群 は，このような分け方ができないので，本来はこの統計からは除くべきものであるが，深さ分 布との関係もみるため, 一応つぎのように分けた,すなわち G-III は上のような定義にしたが う大地震がなく, 時代別にすることができないので, この期間中ある年の前後で地震の数が等 
Table 2. Frequency distributions of magnitude and depth, and values of probability as a measure of the test.

\begin{tabular}{|c|c|c|c|c|c|c|c|c|c|c|c|c|c|}
\hline$D$ & $M$ & G I & G II & G III & GIV & G V & G VI & G VII & G VIII & GIX & GX & GXI & G XII \\
\hline \multirow{4}{*}{$\begin{array}{c}0 \\
1 \\
30\end{array}$} & $4.0-4.9$ & 55 & 1 & 8 & 30 & 10 & 21 & 20 & 14 & 19 & 4 & 0 & 2 \\
\hline & $5.0-5.9$ & 23 & 4 & 3 & 22 & 13 & 17 & 14 & 13 & 26 & 23 & 11 & 31 \\
\hline & $6.0-6.9$ & 2 & 1 & 1 & 3 & 1 & 4 & 3 & 0 & 16 & 8 & 4 & 5 \\
\hline & $7.0-7.9$ & 1 & 0 & 0 & 1 & 1 & 1 & 1 & 0 & 4 & 1 & 1 & 2 \\
\hline \multirow{4}{*}{$\begin{array}{c}40 \\
? \\
60\end{array}$} & $4.0-4.9$ & 6 & 0 & 4 & 3 & 5 & 0 & 0 & 49 & 51 & 4 & 3 & 27 \\
\hline & $5.0-5.9$ & 8 & 23 & 1 & 1 & 0 & 0 & 0 & 21 & 54 & 24 & 16 & 69 \\
\hline & $6.0-6.9$ & 1 & 2 & 1 & 1 & 0 & 0 & 0 & 3 & 7 & 12 & 3 & 14 \\
\hline & $7.0-7.9$ & 0 & 1 & 0 & 0 & 0 & 0 & 0 & 0 & 0 & 0 & 0 & 1 \\
\hline \multirow{2}{*}{$P$} & $(4567)$ & .015 & .068 & .37 & .12 & - & - & - & .053 & $7.9 \times 10^{-7}$ & .073 & .030 & $4.3 \times 10^{-4}$ \\
\hline & $(567)$ & .27 & .36 & .60 & .26 & - & - & - & .26 & $5.3 \times 10^{-5}$ & .16 & .16 & $4.9 \times 10^{-8}$ \\
\hline
\end{tabular}

Table 3. Frequency distributions of magnitude and time, and values of probability as a measure of the test.

\begin{tabular}{|c|c|c|c|c|c|c|c|c|c|c|c|c|c|}
\hline$T$ & $M$ & G I & G II & G III & GIV & G V & G VI & G VII & G VII & GIX & $G X$ & G XI & G XII \\
\hline \multirow{4}{*}{ before } & $4.0-4.9$ & 25 & 0 & 4 & 7 & 5 & 1 & 0 & 22 & 26 & 4 & 0 & 12 \\
\hline & $5.0-5.9$ & 23 & 2 & 3 & 3 & 0 & 2 & 0 & 11 & 27 & 27 & 0 & 50 \\
\hline & $6.0-6.9$ & 1 & 0 & 2 & 1 & 0 & 0 & 0 & 0 & 1 & 12 & 0 & 11 \\
\hline & $7.0-7.9$ & 0 & 0 & 0 & 0 & 0 & 0 & 0 & 0 & 0 & 1 & 0 & 1 \\
\hline \multirow{4}{*}{ middle } & $4.0-4.9$ & 9 & 1 & & 10 & 7 & 16 & 15 & & 4 & & 0 & 4 \\
\hline & $5.0-5.9$ & 0 & 17 & & 17 & 11 & 18 & 13 & & 23 & & 7 & 40 \\
\hline & $6.0-6.9$ & 0 & 3 & & 3 & 0 & 4 & 2 & & 16 & & 3 & 6 \\
\hline & $7.0-7.9$ & 1 & 1 & & 1 & 1 & 1 & 1 & & 4 & & 1 & 2 \\
\hline \multirow{4}{*}{ after } & $4.0-4.9$ & 27 & 0 & 8 & 16 & 3 & 4 & 5 & 41 & 40 & 4 & 3 & 13 \\
\hline & $5.0-5.9$ & 8 & 8 & 1 & 3 & 2 & 1 & 1 & 23 & 30 & 20 & 20 & 10 \\
\hline & $6.0-6.9$ & 2 & 0 & 0 & 0 & 1 & 0 & 1 & 3 & 6 & 8 & 4 & 2 \\
\hline & $7.0-7.9$ & 0 & 0 & 0 & 0 . & 0 & 0 & 0 & 0 & 0 & 0 & 0 & 0 \\
\hline \multirow{5}{*}{$P$} & $(4567)$ & $9.2 \times 10^{-6}$ & .13 & -2 & $2.0 \times 10^{-5}$ & .0015 & .028 & .064 & - & $9.5 \times 10^{-15}$ & .12 & .035 & $7.3 \times 10^{-8}$ \\
\hline & $(456)$ & .0060 & - & .045 & - & .0018 & .034 & .079 & .14 & $2.1 \times 10^{-12}$ & - & .12 & $3.5 \times 10^{-7}$ \\
\hline & (567) & - & .19 & - & .19 & $(.17)$ & .51 & .27 & - & $1.3 \times 10^{-6}$ & .19 & .10 & .028 \\
\hline & (45) & - & - & .19 & - & $3.9 \times 10^{-}$ & 076 & .19 & .49 & $1.9 \times 10^{-5}$ & .49 & .43 & $7.1 \times 10^{-6}$ \\
\hline & (56) & .20 & - & - & .25 & - & - & - & .33 & $5.3 \times 10^{-5}$ & .32 & .33 & .16 \\
\hline
\end{tabular}

しくなるようなところを選び,この年の前を前期, 後を後期としてある. また G-VIII と G-X は,この期間中明らかな活動期が 2 回あつたので, 上の定義とは別に, 前の活動期を前期, 後 のものを後期として統計してある.これらの統計結果を, Table 3 に示す.

\section{§4. むす ひ}

Table 2 および Table 3 に示した結果から,つぎのことが結論される.すなわち, 
1. 福島県沖 (G-IX) および十勝沖 (G-XII) に発生する地震の $M$ は, それらの深さに対 して無関係であるとはいえない，つまり，これらの地域では，深さ約 $40 \mathrm{~km}$ を境にしてそれ よりも浅い部分と樑い部分（最深 $70 \mathrm{~km}$ ) とに分けて考えると，これら両部分における地震 の $M$ の分布は異なるものであるといえる.

2. 地震の $M$ が上記の意味における時間と相関を示すかどうかは, Table 3 に明らかなよ うに，約半数のグループが有意な相関を示しているといえる.

それぞれ, 検定に用いた地震の数が少ないので, これ以上の推論を進めることは将来の研究 にまつ外はない.

おわりに，御指導下さつた松沢，浅田，本多各先生，および本多研究室の皆様に感謝する.

\section{文献}

フィッシャー (遠藤・铪谷訳) 昭和 27 , 研究者のための統計的方法, 34-187.

佐藤良一郎 昭和 25 , 少数例適用無相関検定法, 40-125.

Tsuboi, C. 1958, Earthquake Province-Domain of Sympathetic Seismic Activities, Jour. of Phys. of the Earth, 6, 35-49. 